Archive for

Organic Chemistry

Arkivoc 2017, part ii, 534-545

\title{
The influence of salt additives on macrocyclic product distributions in double-amidation reactions
}

\author{
Grzegorz Pikus, Ewa Paśniczek, and Janusz Jurczak* \\ Institute of Organic Chemistry, Polish Academy of Sciences, Kasprzaka 44/52, 01-224 Warsaw, Poland \\ E-mail: jurczak_group@icho.edu.pl
}

Dedicated to Professor Jacek Młochowski on the occasion of his $80^{\text {th }}$ birthday

Received 08-02-2016

Accepted 11-08-2016

Published on line 01-24-2017

\section{Abstract}

We present an improvement of our own method for synthesising macrocyclic compounds via doubleamidation reactions of aromatic dimethyl esters with five oxa-aliphatic $\alpha, \omega$-diamines of different lengths, leading to a large library of potential ion receptors. We studied the influence of various inorganic salts ( $\mathrm{NaCl}$, $\mathrm{KCl}, \mathrm{CsCl}, \mathrm{NH}_{4} \mathrm{Cl}, \mathrm{MgSO}_{4}, \mathrm{CaCl}_{2}, \mathrm{CuSO}_{4}$ ) on the macrocyclization reaction. The results were analyzed in terms of substrate conversion and distribution of products, using high performance liquid chromatography (HPLC).

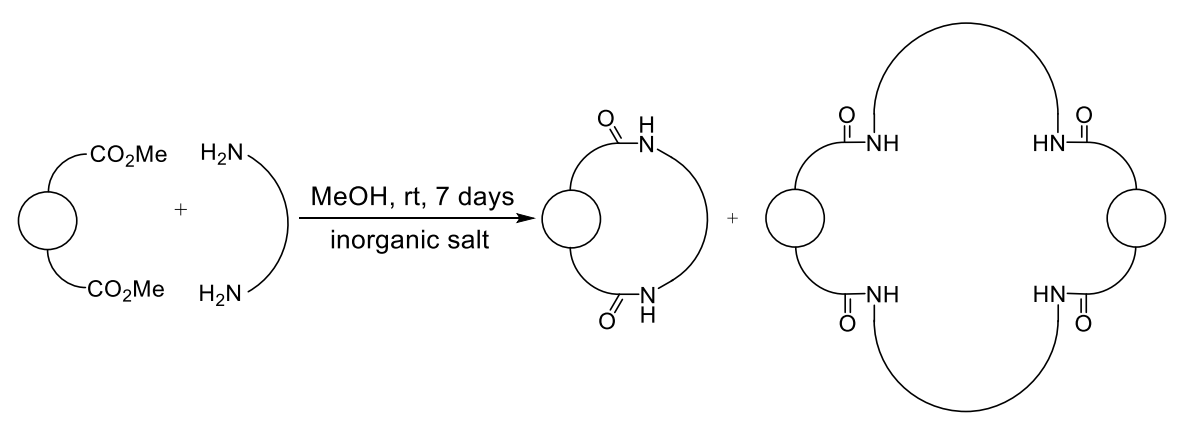

Keywords: Double-amidation reactions, macrocyclization, template effect, macrocyclic lactams, static combinatorial libraries 


\section{Introduction}

The inclusion properties of macrocyclic compounds constitute a very interesting subject of study - the search for selectively complexing receptors is significant in chemistry and biology as well as in medicine. ${ }^{1-4}$ Therefore, shortly after the publication of the pioneering work on the complexation of alkali metal ions by crown ethers, papers examining the synthesis and properties of modified crown ethers started to appear in the literature. In the 1970s, aromatic and/or heteroaromatic systems were introduced into the crown structure, owing to their limited lability. ${ }^{5-7}$ Modifications involving the replacement of oxygen atoms with nitrogen, sulfur, and other heteroatoms and the introduction of various functionalities were also studied. The most important step in each synthesis of macrocyclic compounds is the macrocyclization reaction. One of the possible macrocyclization variants consists in binding the ends of two linear molecules to close the macroring by means of two newly formed bonds. The closure of the macrocycle requires reactive, at least bifunctional, substrates, and one has to take into account that such competitive reactions will lead to mixtures of linear, branched, and cyclic oligomers as shown in Scheme 1.

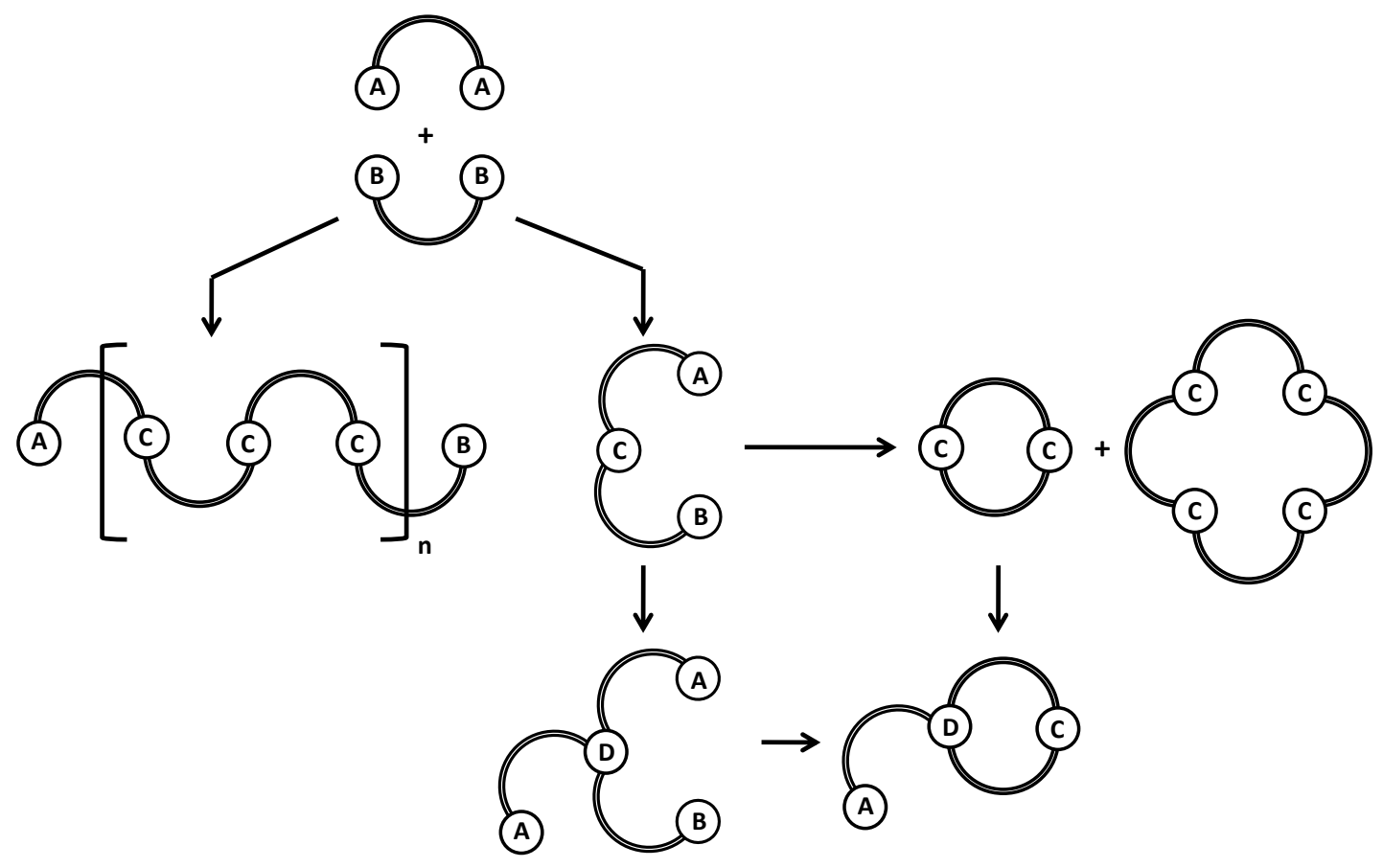

\section{Scheme 1}

Unfortunately, the reaction conditions typical in organic chemistry prefer linear polymerization over a macrocyclization reaction. Because of that, since the very beginnings of supramolecular chemistry, special attention has been paid to overcoming the problems of synthesis: in order to form the specific macrocyclic product, the long and usually flexible intermediate molecule has to adopt a proper, pseudocyclic conformation, and as a consequence, relying only on random factors would usually yield a complex mixture of products, containing only a trace of the desired macrocyclic compound. Nevertheless, present-day supramolecular chemistry has found several synthetic routes allowing for macrocyclization reactions with satisfactory yields. These methods, minimizing the probability of side reactions, are based on limiting the 
frequency of molecular collisions (the high-dilution ${ }^{8-10}$ and high-pressure methods ${ }^{11-15}$ ) or on enforcing the proper conformation of substrates (the template method and procedures making use of preorganization under the influence of external factors). ${ }^{14,16-19}$ Very recently, several research groups have introduced a new approach to this synthetic problem, namely combinatorial chemistry techniques in both variants - static and dynamic. 20

Given the above, we decided to combine the static combinatorial variant of macrocyclization with the template approach, and to investigate their influence in the synthesis of macrocyclic amides, comparing the product distributions with those obtained for nontemplated reactions.

\section{Results and Discussion}

As we have reported, ${ }^{21,22}$ aromatic dimethyl dicarboxylic diesters $\mathbf{1 - 3}$ react with $\alpha, \omega$-diamines $\mathbf{4 - 8}$ of differing length (Figure 1) to afford mixtures of macrocyclic diamides and tetraamides via double-amidation reactions, carried out in methanol at room temperature, without any additives (Scheme 2).

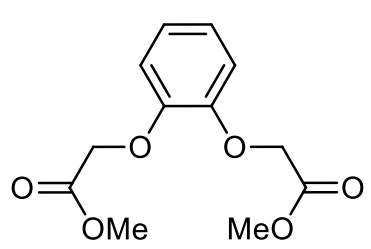

1<smiles>COC(=O)COc1cccc(OCC(=O)OC)c1</smiles>

2<smiles>COC(=O)COc1ccc(OCC(=O)OC)cc1</smiles>

3

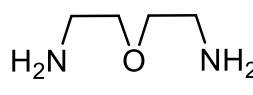

4

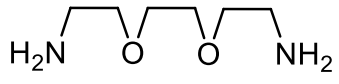

5

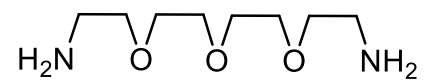

6

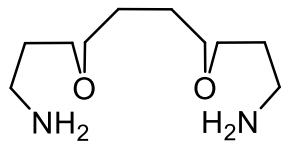

7

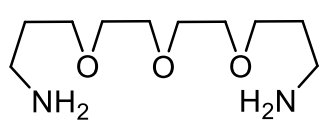

8

\section{Figure 1}




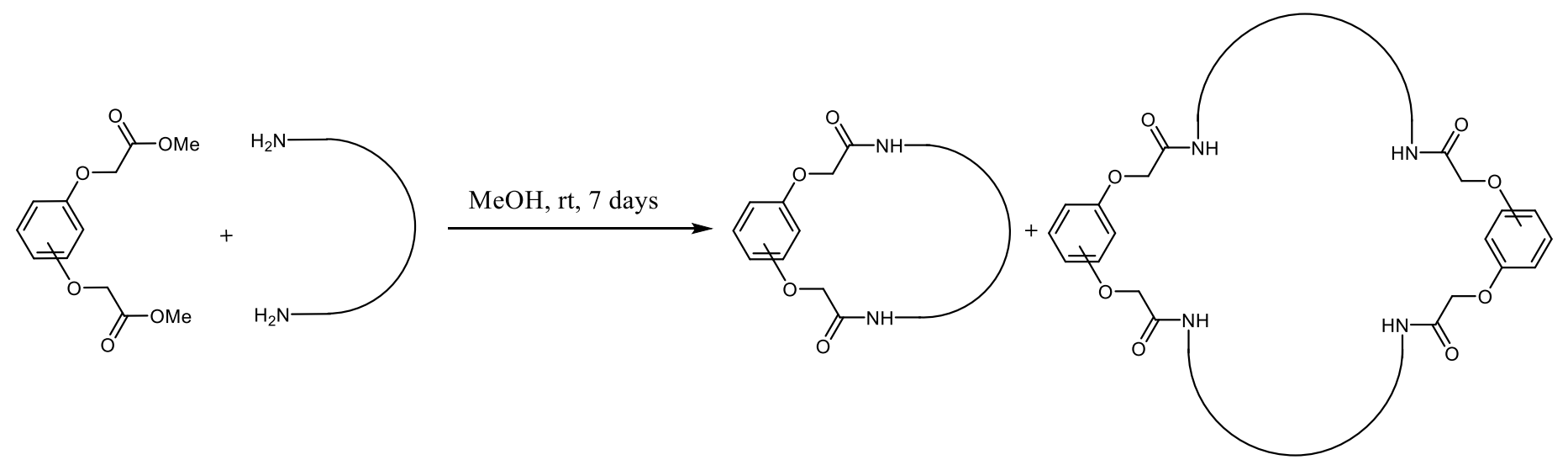

1-3

4-8

$9-23$

24-38

Scheme 2

We decided to repeat these syntheses under nontemplated conditions and carefully re-analyzed all the macrocyclic products obtained (see Supplementary Material). In almost all cases we obtained mixtures of macrocyclic diamides and tetraamides, as shown in Figure 2. The results of these studies are presented in Table 1. Only in two cases did we not isolate macrocyclic tetraamides $\mathbf{2 6}$ and $\mathbf{3 1}$ from reactions of diamine $\mathbf{6}$ with diesters 1 and $\mathbf{2}$, respectively. ${ }^{22}$

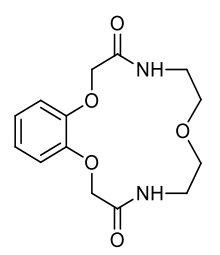

$9(77 \%)$<smiles>O=C(COc1ccccc1OCC(=O)NCCCOCCOCCO)NCCO</smiles>

$13(55 \%)$<smiles></smiles>

17 (42\%)

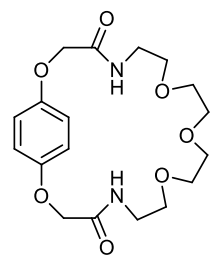

Diamides (DA)<smiles>O=C1CCOCCOCCNC(=O)COc2ccccc2OC1</smiles>

$10(75 \%)$

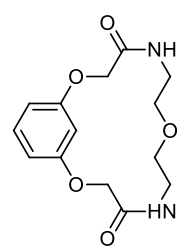

$14(25 \%)$<smiles></smiles>

$18(40 \%)$<smiles>O=C(COc1ccccc1OCC(=O)NCCOCCOCCO)NCCO</smiles>

$11(29 \%)$<smiles>O=C1CCOCCOCCNC(=O)COc2cccc(c2)OC1</smiles>

$15(22 \%)$<smiles>CNC(=O)COc1ccc(OCC(=O)NCCOCCNC(=O)c2ccccc2)cc1</smiles>

$19(1 \%)$<smiles>O=C(COc1ccccc1OCC(=O)NCCCOCCCCO)NCCO</smiles>

$12(40 \%)$<smiles></smiles>

$16(30 \%)$

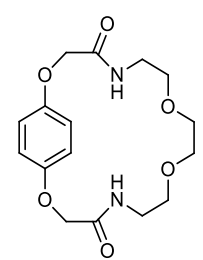

$20(20 \%)$<smiles></smiles><smiles>O=C(COc1ccc(OCC(=O)NCCCOCCOCCCNCCCO)cc1)NCCO</smiles> 
$21(18 \%)$
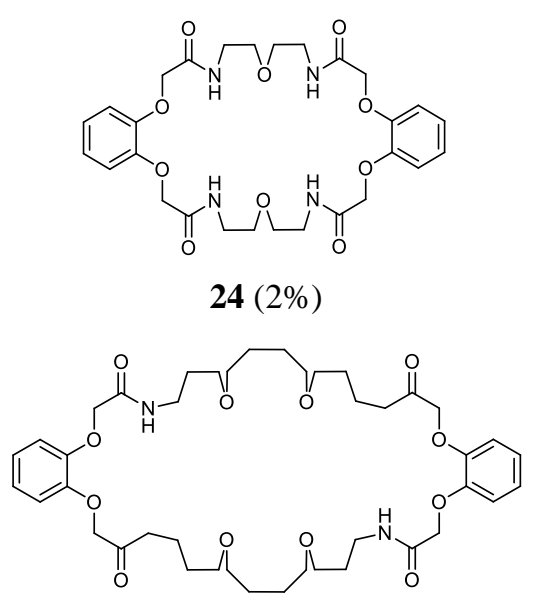

27 (8\%)

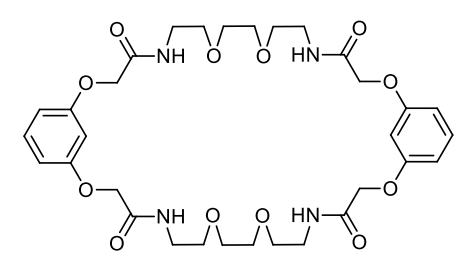

$30(6 \%)$

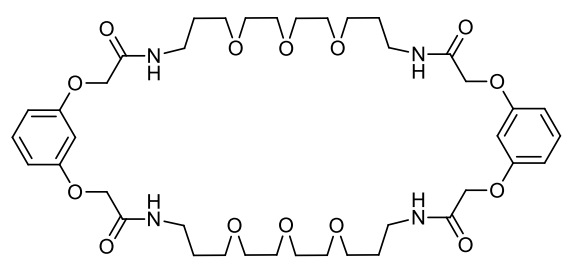

33 (3\%)

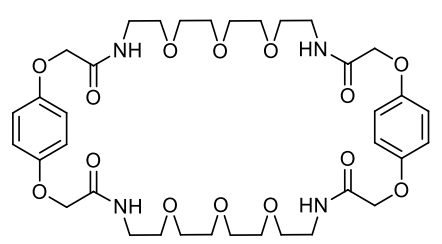

$36(2 \%)$
$22(35 \%)$

$23(28 \%)$

\section{Tetramides (TA)}

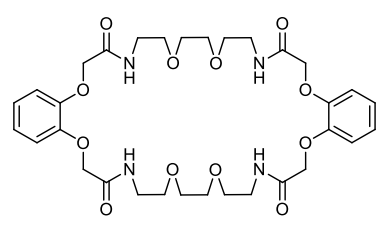

$25(5 \%)$

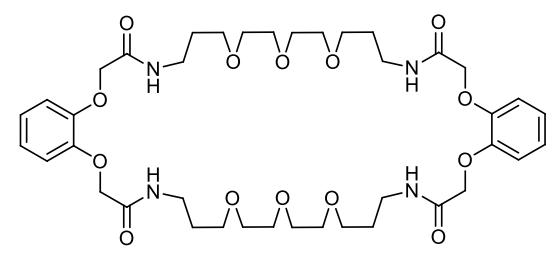

$28(6 \%)$

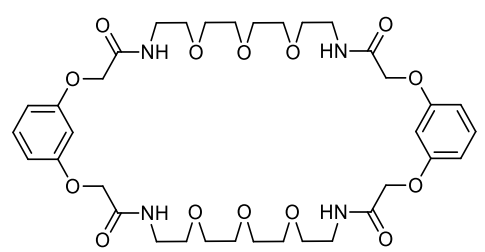

31 (not isolated)

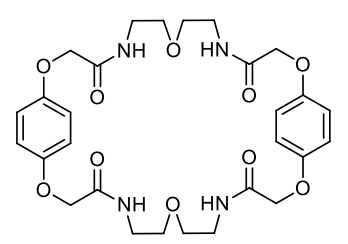

$34(10 \%)$

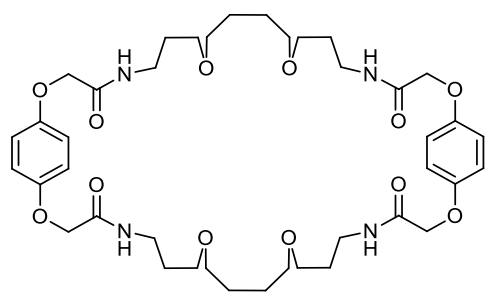

$37(6 \%)$

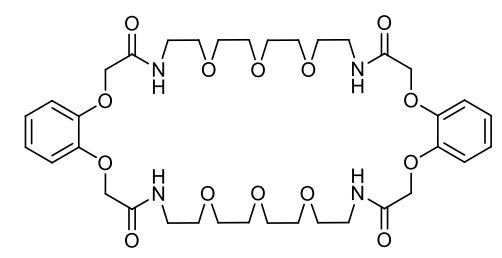

26 (not isolated)

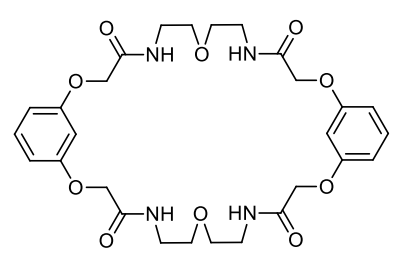

$29(4 \%)$

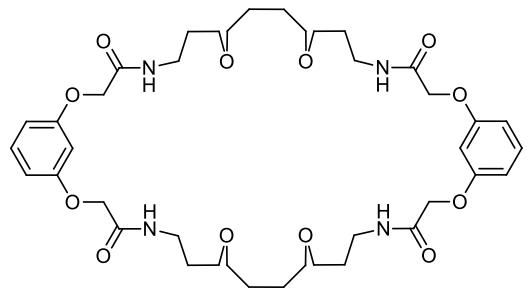

$32(18 \%)$

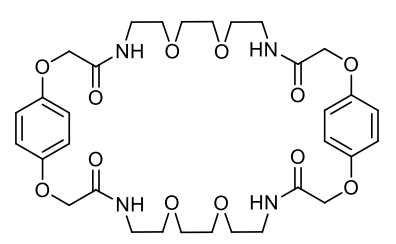

35 (11\%)

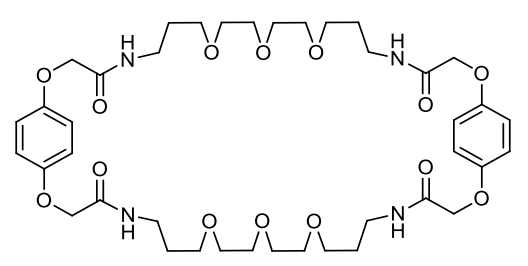

$38(4 \%)$

Figure 2. Diamides and tetramides formed in nontemplated reactions.

As mentioned above, complex reaction mixtures might contain macrocyclic amides as well as linear oligomers and traces of substrates. In order to identify these compounds quantitatively, we adapted the HPLC method which we had previously used successfully for analysis of dynamic combinatorial libraries of macrocyclic imines. ${ }^{23,24}$ Based on the library of macrocyclic amides (Figure 2) we were able to measure the conversion of aromatic dimethyl esters (1-3) and compare the proportion between macrocyclic diamides 9-23 and tetraamides 24-38 as a molar ratio, after calibrating the UV detector (see Supplementary Materials). 
Table 1. Nontemplated macrocyclization reactions leading to mixtures of diamides (DA) and tetraamides (TA)

\begin{tabular}{|c|c|c|c|c|c|c|}
\hline \multirow{2}{*}{$\begin{array}{c}\text { Entry } \\
1\end{array}$} & \multirow[t]{2}{*}{ Diester } & \multirow{2}{*}{$\begin{array}{c}\text { Diamine } \\
4\end{array}$} & \multirow{2}{*}{$\begin{array}{c}\text { Conversion, }^{\mathrm{a}} \\
\%\end{array}$} & \multicolumn{3}{|c|}{$\begin{array}{c}\text { Product distribution }^{\mathrm{a}} \\
\mathrm{DA}: \mathrm{TA}=\mathrm{X}: \mathrm{Y}\end{array}$} \\
\hline & & & & $9: 24$ & $=$ & $99: 1$ \\
\hline 2 & & 5 & 82 & $10: 25$ & $=$ & $99: 1$ \\
\hline 3 & 1 & 6 & 48 & $11: 26$ & $=$ & $100: 0$ \\
\hline 4 & & 7 & 100 & $12: 27$ & $=$ & $92: 8$ \\
\hline 5 & & 8 & 78 & $13: 28$ & $=$ & $92: 8$ \\
\hline 6 & & 4 & 36 & $14: 29$ & $=$ & $93: 7$ \\
\hline 7 & & 5 & 82 & $15: 30$ & $=$ & $94: 6$ \\
\hline 8 & 2 & 6 & 64 & $16: 31$ & $=$ & $100: 0$ \\
\hline 9 & & 7 & 90 & $17: 32$ & $=$ & $89: 11$ \\
\hline 10 & & 8 & 89 & $18: 33$ & $=$ & $89: 11$ \\
\hline 11 & & 4 & 47 & $19: 34$ & $=$ & $26: 74$ \\
\hline 12 & & 5 & 41 & $20: 35$ & $=$ & $86: 14$ \\
\hline 13 & 3 & 6 & 29 & $21: 36$ & $=$ & $93: 7$ \\
\hline 14 & & 7 & 100 & $22: 37$ & $=$ & $85: 15$ \\
\hline 15 & & 8 & 85 & $23: 38$ & $=$ & $85: 15$ \\
\hline
\end{tabular}

${ }^{a}$ Reaction time was 7 days, except for reactions of 1-3 with diamines 6 and 8 (entries 3, 5, $8,10,13$, and 15), where it was 21 days.

The best conversions were obtained for reactions involving diamine 7 (Table 1, entries 4, 9, and 14). Analysing the nontemplated product distribution for these reactions, we observed that the proportions of macrocyclic products are closely related to the geometrical requirements of the substrates. The reactions of ortho-diester 1 with five diamines 4-8 produced mainly macrocyclic diamides (entries 1-5). However, the content of tetraamides increased for longer diamines (entries 4 and 5), and this trend is highlighted for metaand para-isomers (entries 9, 10 and 14, 15, respectively). The reaction of diamine 4 with para-diester 3 deserves particular attention, because in this case the macrocyclic tetraamide $\mathbf{3 4}$ dominated over the diamide 19 (entry 11).

Next we studied the influence of the addition of inorganic salts on the macrocyclization reactions of dimethyl esters 1-3 with diamides 4-8, carried out under conditions analogous to those of the nontemplated process. Each experiment was performed by mixing one equivalent of diester with one equivalent of diamine and one equivalent of a chosen inorganic salt (see Experimental Section). The results of these experiments are shown in Tables 2-5 and compared with those found for nontemplated reactions.

The effect of sodium chloride addition on the conversion of substrates is practically negligible (Table 2 ). The product distribution is also only slightly affected as compared with nontemplated conditions, including the reverse direction of the reaction of diester 3 with diamine 4 (Table 2, entry 11). The influence of potassium chloride as an additive (Table 3 ) on both conversion and product distribution was found to be very similar. 
Table 2. NaCl-templated macrocyclization reactions leading to mixtures of diamides (DA) and tetraamides (TA)

\begin{tabular}{|c|c|c|c|c|c|c|}
\hline \multirow{2}{*}{$\begin{array}{c}\text { Entry } \\
1\end{array}$} & \multirow[t]{2}{*}{ Diester } & \multirow{2}{*}{$\begin{array}{c}\text { Diamine } \\
4\end{array}$} & \multirow{2}{*}{$\begin{array}{c}\text { Conversion, } \\
\% \\
67\end{array}$} & \multicolumn{3}{|c|}{$\begin{array}{c}\text { Product distribution } \\
\mathrm{DA}: \mathrm{TA}=\mathrm{X}: \mathrm{Y}\end{array}$} \\
\hline & & & & $9: 24$ & $=$ & $100: 0$ \\
\hline 2 & & 5 & 88 & $10: 25$ & $=$ & $99: 1$ \\
\hline 3 & 1 & 6 & 52 & $11: 26$ & $=$ & $100: 0$ \\
\hline 4 & & 7 & 100 & $12: 27$ & $=$ & $90: 10$ \\
\hline 5 & & 8 & 100 & $13: 28$ & $=$ & $89: 11$ \\
\hline 6 & & 4 & 49 & $14: 29$ & $=$ & $91: 9$ \\
\hline 7 & & 5 & 64 & $15: 30$ & $=$ & $95: 5$ \\
\hline 8 & 2 & 6 & 63 & $16: 31$ & $=$ & $100: 0$ \\
\hline 9 & & 7 & 86 & $17: 32$ & $=$ & $90: 10$ \\
\hline 10 & & 8 & 95 & $18: 33$ & $=$ & $86: 14$ \\
\hline 11 & & 4 & 31 & $19: 34$ & $=$ & $20: 80$ \\
\hline 12 & & 5 & 62 & $20: 35$ & $=$ & $81: 19$ \\
\hline 13 & 3 & 6 & 30 & $21: 36$ & $=$ & $93: 7$ \\
\hline 14 & & 7 & 86 & $22: 37$ & $=$ & $82: 18$ \\
\hline 15 & & 8 & 94 & $23: 38$ & $=$ & $86: 14$ \\
\hline
\end{tabular}

Table 3. $\mathrm{KCl}$-templated macrocyclization reactions leading to mixtures of diamides (DA) and tetraamides (TA)

\begin{tabular}{|c|c|c|c|c|c|c|}
\hline \multirow{2}{*}{$\begin{array}{c}\text { Entry } \\
1\end{array}$} & \multirow[t]{2}{*}{ Diester } & \multirow{2}{*}{$\begin{array}{c}\text { Diamine } \\
\mathbf{4}\end{array}$} & \multirow{2}{*}{$\begin{array}{c}\text { Conversion, } \\
\% \\
60\end{array}$} & \multicolumn{3}{|c|}{$\begin{array}{c}\text { Product distribution } \\
\qquad \mathrm{DA}: \mathrm{TA}=\mathrm{X}: \mathrm{Y}\end{array}$} \\
\hline & & & & $9: 24$ & $=$ & $100: 0$ \\
\hline 2 & & 5 & 95 & $10: 25$ & $=$ & $98: 2$ \\
\hline 3 & 1 & 6 & 32 & $11: 26$ & $=$ & $100: 0$ \\
\hline 4 & & 7 & 100 & $12: 27$ & $=$ & $90: 10$ \\
\hline 5 & & 8 & 98 & $13: 28$ & $=$ & $88: 12$ \\
\hline 6 & & 4 & 35 & $14: 29$ & $=$ & $92: 8$ \\
\hline 7 & & 5 & 61 & $15: 30$ & $=$ & $94: 6$ \\
\hline 8 & 2 & 6 & 54 & $16: 31$ & $=$ & $100: 0$ \\
\hline 9 & & 7 & 100 & $17: 32$ & $=$ & $91: 9$ \\
\hline 10 & & 8 & 81 & $18: 33$ & $=$ & $91: 9$ \\
\hline 11 & & 4 & 59 & $19: 34$ & $=$ & $17: 83$ \\
\hline 12 & & 5 & 49 & $20: 35$ & $=$ & $82: 18$ \\
\hline 13 & 3 & 6 & 29 & $21: 36$ & $=$ & $93: 7$ \\
\hline 14 & & 7 & 46 & $22: 37$ & $=$ & $93: 7$ \\
\hline 15 & & 8 & 93 & $23: 38$ & $=$ & $84: 14$ \\
\hline
\end{tabular}

The addition of caesium chloride had a much more pronounced influence on conversion, especially for the reactions of amines 4-8 with diesters 1 and 2 (Table 4, entries 1-3, 5-7, 9, and 10). Nevertheless, we did not observe any major improvement in the distribution of macrocyclic products. 
Table 4. CsCl-templated macrocyclization reactions leading to mixtures of diamides (DA) and tetraamides (TA)

\begin{tabular}{|c|c|c|c|c|c|c|}
\hline \multirow{2}{*}{$\begin{array}{c}\text { Entry } \\
\qquad 1\end{array}$} & \multirow[t]{2}{*}{ Diester } & \multirow{2}{*}{$\begin{array}{c}\text { Diamine } \\
4\end{array}$} & \multirow{2}{*}{$\begin{array}{c}\text { Conversion, } \\
\% \\
77\end{array}$} & \multicolumn{3}{|c|}{$\begin{array}{c}\text { Product distribution } \\
\qquad \mathrm{DA}: \mathrm{TA}=\mathrm{X}: \mathrm{Y}\end{array}$} \\
\hline & & & & $9: 24$ & $=$ & $100: 0$ \\
\hline 2 & & 5 & 93 & $10: 25$ & $=$ & $99: 1$ \\
\hline 3 & 1 & 6 & 43 & $11: 26$ & $=$ & $100: 0$ \\
\hline 4 & & 7 & 100 & $12: 27$ & $=$ & $90: 10$ \\
\hline 5 & & 8 & 96 & $13: 28$ & $=$ & $91: 9$ \\
\hline 6 & & 4 & 51 & $14: 29$ & $=$ & $91: 9$ \\
\hline 7 & & 5 & 80 & $15: 30$ & $=$ & $93: 7$ \\
\hline 8 & 2 & 6 & 62 & $16: 31$ & $=$ & $100: 0$ \\
\hline 9 & & 7 & 100 & $17: 32$ & $=$ & $90: 10$ \\
\hline 10 & & 8 & 100 & $18: 33$ & $=$ & $87: 13$ \\
\hline 11 & & 4 & 55 & $19: 34$ & $=$ & $27: 73$ \\
\hline 12 & & 5 & 68 & $20: 35$ & $=$ & $83: 17$ \\
\hline 13 & 3 & 6 & 32 & $21: 36$ & $=$ & $90: 10$ \\
\hline 14 & & 7 & 65 & $22: 37$ & $=$ & $91: 9$ \\
\hline 15 & & 8 & 79 & $23: 38$ & $=$ & $87: 13$ \\
\hline
\end{tabular}

Using ammonium chloride as the salt additive, we observed a negative impact on conversion, especially for the reaction of ester 3 with diamines 4-8. However, in some cases the addition of $\mathrm{NH}_{4} \mathrm{Cl}$ improved the reaction rate (Table 5, entries 3,8-10). Although the conversion in many reactions was low, the content of macrocyclic tetraamides was much higher than in nontemplated reactions (entries $6,7,12$, and 13). For reactions of diesters 1-3 with the longest diamines $\mathbf{7}$ and $\mathbf{8}$, the presence of ammonium chloride inhibited the formation of macrocyclic tetraamides (entries $4,5,9,10,14$, and 15 ).

We also studied the influence of three other inorganic salts $\left(\mathrm{MgSO}_{4}, \mathrm{CaCl}_{2}\right.$, and $\left.\mathrm{CuSO}_{4}\right)$ on the model reaction of diester $\mathbf{2}$ with diamine 7 (Table 6). Magnesium sulfate and calcium chloride (Table 6, entries 2 and 4) increased the conversion of diester 2; however, the content of tetraamide 32 decreased from 11 to 5 and 2 mol\%, respectively. On the other hand, copper sulfate (entry 4 ) inhibited the macrocyclization process of the model reaction. 
Table 5. $\mathrm{NH}_{4} \mathrm{Cl}$-templated macrocyclization reactions leading to mixtures of diamides (DA) and tetraamides (TA)

\begin{tabular}{|c|c|c|c|c|c|c|}
\hline \multirow{2}{*}{$\begin{array}{c}\text { Entry } \\
1\end{array}$} & \multirow[t]{2}{*}{ Diester } & \multirow{2}{*}{$\begin{array}{c}\text { Diamine } \\
\mathbf{4}\end{array}$} & \multirow{2}{*}{$\begin{array}{c}\text { Conversion, } \\
\% \\
63\end{array}$} & \multicolumn{3}{|c|}{$\begin{array}{c}\text { Product distribution } \\
\mathrm{DA}: \mathrm{TA}=\mathrm{X}: \mathrm{Y}\end{array}$} \\
\hline & & & & $9: 24$ & $=$ & $100: 0$ \\
\hline 2 & & 5 & 81 & $10: 25$ & $=$ & $97: 3$ \\
\hline 3 & 1 & 6 & 91 & $11: 26$ & $=$ & $100: 0$ \\
\hline 4 & & 7 & 43 & $12: 27$ & $=$ & $96: 4$ \\
\hline 5 & & 8 & 73 & $13: 28$ & $=$ & $97: 3$ \\
\hline 6 & & 4 & 13 & $14: 29$ & $=$ & $80: 20$ \\
\hline 7 & & 5 & 12 & $15: 30$ & $=$ & $74: 26$ \\
\hline 8 & 2 & 6 & 97 & $16: 31$ & $=$ & $100: 0$ \\
\hline 9 & & 7 & 95 & $17: 32$ & $=$ & $96: 4$ \\
\hline 10 & & 8 & 96 & $18: 33$ & $=$ & $96: 4$ \\
\hline 11 & & 4 & 0 & $19: 34$ & $=$ & $0: 0$ \\
\hline 12 & & 5 & 6 & $20: 35$ & $=$ & $29: 71$ \\
\hline 13 & 3 & 6 & 6 & $21: 36$ & $=$ & $29: 71$ \\
\hline 14 & & 7 & 51 & $22: 37$ & $=$ & $97: 3$ \\
\hline 15 & & 8 & 15 & $23: 38$ & $=$ & $100: 0$ \\
\hline
\end{tabular}

Table 6. $\mathrm{MgSO}_{4^{-}}, \mathrm{CaCl}_{2^{-}}$and $\mathrm{CuSO}_{4}$-templated macrocyclization reactions leading to mixtures of diamides (DA) and tetraamides (TA)

\begin{tabular}{cccccc}
\hline & & \multicolumn{4}{c}{ Composition of the library } \\
Entry & Template & \multicolumn{4}{c}{$\mathbf{2 + \mathbf { 7 }}$} \\
\cline { 3 - 6 } & & Time, days & Conversion, \% & Diamide17 & Tetraamide 32 \\
\hline 1 & none & 7 & 90 & 89 & 11 \\
2 & $\mathrm{MgSO}_{4}$ & 6 & 98 & 95 & 5 \\
3 & $\mathrm{CaCl}_{2}$ & 3 & 100 & 98 & 2 \\
4 & $\mathrm{CuSO}_{4}$ & 5 & 18 & 100 & 0 \\
\hline
\end{tabular}

\section{Conclusions}

We obtained 28 macrocyclic products (9-38) and studied the influence of various salts $\left(\mathrm{NaCl}, \mathrm{KCl}, \mathrm{CsCl}, \mathrm{NH}{ }_{4} \mathrm{Cl}\right.$, $\mathrm{MgSO}_{4}, \mathrm{CaCl}_{2}$, and $\mathrm{CuSO}_{4}$ ) on macrocyclization via double-amidation reactions, finding that the conversion rates and product distributions are closely related to geometrical requirements. The reaction of ortho-diester $\mathbf{1}$ with shorter diamines $\mathbf{4}$ and $\mathbf{5}$ gave mainly macrocyclic diamides $\mathbf{9}$ and $\mathbf{1 0}$ with high yields 77\% and 75\%, respectively. The geometry of the substrates and proximity of reacting centers promote the synthesis of macrocyclic diamides. However, with increasing diamine length, yields of macrocyclic tetraamides increased. The results obtained for the reactions of meta-diester 2 with diamines 4-8 were similar. On the other hand, the reaction of para-diester $\mathbf{3}$ with the shortest diamine $\mathbf{4}$ led to tetraamide $\mathbf{3 4}$ as the major product though its isolated yield was only $10 \%$. 
As we have proved, non-templated macrocyclization via double-amidation reactions of dimethyl dicarboxylic esters with $\alpha, \omega$-diamines in methanol gave excellent yields. Methanol is a challenging solvent to study the influence of inorganic salts on chemical reactions because of strong interactions such as solvation effects, dense hydrogen bond systems, etc. Although we did not observe any major changes for some salts added, like sodium and potassium chloride, a slight improvement in substrate conversion for cesium chloride was noticed. An interesting observation was made for ammonium chloride, which had inhibiting properties for most of macrocyclic reactions. This is probably connected with the acidity of this salt because, as we reported, ${ }^{18}$ basic condition improved double-amidation reactions between dimethyl dicarboxylic esters and diamines in methanol, addition of a weak acid would have been counterproductive. Copper sulfate also had a negative influence on the macrocyclization process. In this case the inhibiting effect might have been caused by an ability of copper(II) to create a complex with diaminoether $7 .^{25}$

The above-mentioned reaction conditions could be utilized in the synthesis of macrocyclic diamides and tetraamides, as intermediates for the construction of potential ion receptors.

\section{Experimental Section}

All reagents were obtained from commercial sources and used as received. Melting points were measured with a Koefler type (Boetius M) hot-stage apparatus. The column chromatography experiments were carried out using silica Kieselgel 60 (230-400 mesh). The thin-layer chromatography analyses were carried out using Merck DC Kieselgel $60 \mathrm{~F}_{254}$ plates. ${ }^{1} \mathrm{H}$ NMR spectra were recorded on a Varian Mercury 400 spectrometer (400 $\mathrm{MHz}$ ) in $\mathrm{CDCl}_{3} .{ }^{13} \mathrm{C}$ NMR spectra were recorded on a Varian Mercury 400 spectrometer $(100 \mathrm{MHz})$. All chemical shifts are quoted in parts per million $(\mathrm{ppm}, \delta)$ relative to tetramethylsilane $(\delta 0.00 \mathrm{ppm})$ and coupling constants $(J)$ are given in Hertz. Splitting patterns are designated as follows: s, singlet; $d$, doublet; $t$, triplet; $q$, quartet; m, multiplet.

General procedure for the synthesis of macrocyclic di- and tetraamides. All macrocyclic compounds were obtained as previously described. ${ }^{20,21}$ The corresponding diester (1-3) (10 mmol) and diamine (4-8) (10 mmol) were dissolved in $\mathrm{MeOH}(100 \mathrm{ml})$. The reaction mixture was stirred for $7 \mathrm{~d}$ at $\mathrm{rt}$. After completion of the reaction (monitored by TLC), the solvent was evaporated and the residue was puriofied by chromatography on a silica gel column using $0-5 \%$ solutions of $\mathrm{MeOH} / \mathrm{CH}_{2} \mathrm{Cl}_{2}$. Analytical and spectroscopic data are collected in the Supplementary Materials.

General procedure for HPLC studies of macrocyclization reactions. The corresponding diester (1-3) (0.3 $\mathrm{mmol})$ and diamine $(4-8)(0.3 \mathrm{mmol})$ were dissolved in $\mathrm{MeOH}(10 \mathrm{ml})$. The reaction mixture was stirred for $7 \mathrm{~d}$ at $\mathrm{rt}$ (the templated reactions were prepared analogously by adding one equivalent $-0.3 \mathrm{mmol}$ of chosen inorganic salt to the reaction mixtures). Next $0.1 \mathrm{~mL}$ of a reaction mixture was dissolved in $\mathrm{MeOH}(4 \mathrm{~mL}) \mathrm{and}$ this diluted mixture was analyzed by HPLC: reversed-phase column Bionacom Velocity C18-2, 4.6x250 mm, grin size $5 \mu \mathrm{m}, \lambda=195 \mathrm{~nm}$, gradient $25 \% \rightarrow 50 \% \mathrm{MeCN} / \mathrm{H}_{2} \mathrm{O}, \mathrm{t}=30 \mathrm{~min}$. 


\section{Acknowledgements}

This work was financed by a Polish National Science Centre grant (Maestro UMO-2011/02/A/ST5/00439).

\section{References}

1. Madsen, C. M.; Clausen, M. H. Eur. J. Org. Chem. 2011, 16, 3107.

http://dx.doi.org/10.1002/ejoc.201001715

2. Mallinson, J.; Collins, I. Future Med. Chem. 2012, 4, 1409.

http://dx.doi.org/10.4155/fmc.12.93

3. Yu, X.; Sun, D. Molecules 2013, 18, 6230.

http://dx.doi.org/10.3390/molecules18066230

4. Bashiruddin, N. K.; Suga, H. Curr. Opin. Chem. Biol. 2015, 24, 131.

http://dx.doi.org/10.1016/j.cbpa.2014.11.011

5. Cram, D. J.; Cram, J. M. Science 1974, 183, 803.

http://dx.doi.org/10.1126/science.183.4127.803

6. Cram, D. J.; Bauer, R. H. J. Am. Chem. Soc. 1959, 81, 5971.

http://dx.doi.org/10.1021/ja01531a031

7. Pedersen, C. J. Org. Synth. 1972, 52, 66.

http://dx.doi.org/10.15227/orgsyn.052.0066

8. Ruggli, P. Liebig's Ann. Chem. 1912, 392, 92.

http://dx.doi.org/10.1002/ilac.19123920106

9. Dietrich, B.; Lehn, J. M.; Sauvage, J. P. Tetrahedron 1973, 29, 1629.

http://dx.doi.org/10.1016/S0040-4020(01)83409-8

10. Dietrich, B.; Lehn, J. M.; Sauvage, J. P. Tetrahedron Lett. 1969, 2885.

http://dx.doi.org/10.1016/S0040-4039(01)88299-X

11. Jurczak, J.; Ostaszewski, R.; Sałański, P. J. Chem. Soc., Chem. Commun. 1989, 3, 184.

http://dx.doi.org/10.1039/C39890000184

12. Jurczak, J.; Ostaszewski, R. J. Coord. Chem. 1992, 27, 201.

http://dx.doi.org/10.1080/00958979209407952

13. Jurczak, J.; Ostaszewski, R.; Sałański, P.; Stankiewicz, T. Tetrahedron 1993, 49, 1471.

http://dx.doi.org/10.1016/S0040-4020(01)90199-1

14. Jurczak, J.; Stankiewicz, T.; Sałański, P.; Kasprzyk, S.; Lipkowski, P. Tetrahedron 1993, 49, 1478.

http://dx.doi.org/10.1016/S0040-4020(01)90200-5

15. Jurczak, J.; Kasprzyk, S.; Sałański, P.; Stankiewicz, T. High Press. Res. 1992, 11, 139.

http://dx.doi.org/10.1080/08957959208201699

16. Tabushi, I.; Taniguchi, Y.; Kato, H. Tetrahedron Lett. 1977, 18, 1049.

http://dx.doi.org/10.1016/S0040-4039(01)92825-4

17. Lipkowski, P.; Gryko, D. T.; Jurczak, J.; Lipkowski, J. Tetrahedron Lett. 1998, 39, 3833;

http://dx.doi.org/10.1016/S0040-4039(98)00624-8

18. Gryko, D. T.; Gryko, D.; Jurczak, J., J. Supramol. Chem. 2000, 12, 101.

http://dx.doi.org/10.1080/10610270008029808

19. Dąbrowa, K.; Niedbała, P.; Majdecki, M.; Jurczak J., Org. Lett. 2015, 17, 4774. 
http://dx.doi.org/10.1021/acs.orglett.5b02324

20. Corbett, P. T.; Leclaire, J.; Vial, L.; West, K. R.; Wietor, J.-L.; Sanders, J. K. M., Otto, S. Chem. Rev. 2006, 106, 3652.

http://dx.doi.org/10.1021/cr020452p

21. Gryko, D. T.; Piątek, P.; Jurczak, J. Tetrahedron 1997, 53, 7957.

http://dx.doi.org/10.1016/S0040-4020(97)00480-8

22. Paśniczek, E.; Chmielewski, M. J.; Grzegorzewski, P.; Jurczak, J. Pol. J. Chem. 2006, 80, 899.

23. Ziach, K.; Jurczak, J. Org. Lett. 2008, 10, 5159.

http://dx.doi.org/10.1021/ol802121s

24. Ziach, K.; Obrocka-Hrycyna, A.; Jurczak, J. J. Org. Chem. 2014, 79, 10334.

http://dx.doi.org/10.1021/jo501966q

25. Wu, H. L., Wang, C. P., Zhang, H., Peng, H. P., Wang, F., Russ. J. Coord. Chem. 2016, 42, 170. http://dx.doi.org/10.1134/S1070328416030106 